\title{
Tramadol Iontophoresis Added to Treatment of Knee Osteoarthritis
}

\author{
Diz Osteoartriti Tedavisine Eklenen Tramadol Iyontoforezi
}

\author{
Ayşe Dicle Turhanoğluㄹ, Hayal Güler ${ }^{1}$, Deniz İnanoğlu ${ }^{1}$, Kerem İnanoğlu², Selim Turhanoğlu \\ IMustafa Kemal Üniversitesi Tıp Fakültesi, Fiziksel Tıp ve Rehabilitasyon Anabilim Dalı, Hatay, Turkey \\ ${ }^{2}$ Mustafa Kemal Üniversitesi Tıp Fakültesi, Anesteziyoloji ve Reanimasyon Anabilim Dalı, Hatay, Turkey
}

\begin{abstract}
Objective: The objective of the present study was to investigate whether tramadol iontophoresis added to therapy is superior to the therapy methods alone (transcutaneous electrical nerve stimulation (TENS), hot pack, ultrasound, and exercise therapy) in patients with knee OA.

Materials and Methods: A total of 72 patients who admitted to the outpatient clinic of Physical Medicine and Rehabilitation were included in this study. The diagnosis was based on the American College of Rheumatology (ACR) criteria for knee OA. The patients were randomly separated into two groups. Group 1 received physical therapy and Group 2 received tramadol iontophoresis in addition to the therapy for a period of two weeks. Patients were evaluated according to pain and functional capacity assessed using visual analogue scale (VAS) and Western Ontario McMaster Universities Osteoarthritis Index (WOMAC) before therapy and following the 10th session, and at 1 and 3 months.
\end{abstract}

Results: The mean age and duration of the knee pain were $58.53 \pm 8.38,5.00 \pm 2.66$ years in the control group and $58.15 \pm 7.70$, $4.71 \pm 2.70$ years in the tramadol iontophoresis group. There were no significant differences between groups in the mean age and duration of the knee pain, body mass index (BMI), VAS and WOMAC scores before therapy. Following the 10th session, and after 1 and 3 months, VAS and WOMAC scores were significantly decreased in both groups when compared with the baseline values $(p<0.001)$. VAS scores were significantly lower in the tramadol iontophoresis group compared to controls following the 10th session $(p<0.001)$. However, no significant difference was found between WOMAC scores of the tramadol iontophoresis and control groups ( $p>0.05)$.

Conclusion: We conclude that tramadol iontophoresis added to physical therapy may be useful for relieving pain of knee OA during the treatment period. (Turk J Rheumatol 2010; 25: 174-8)

Key words: Knee osteoarthritis, iontophoresis, tramadol, physical therapy

Received: 29.11.2008 Accepted: 16.05.2009

\section{Özet}

Amaç: Bu çalıșmanın amacı diz OA hastalarında tedaviye eklenen tramadol iyontoforezinin tek bașına uygulanan tedavi yöntemlerine (transkütanöz elektriksel sinir stimülasyonu, sıcak kompres, ultrason ve egzersiz tedavisi) üstün olup olmadığını incelemektir.

Yöntem ve Gereçler: Calıșmaya Fizik Tedavi ve Rehabilitasyon polikliniğine bașvuran 72 hasta dahil edildi. Hastaların tanısı, Amerikan Romatoloji Birliği (ACR) Diz OA kriterlerine göre konuldu. Hastalar rastgele iki gruba ayrıldı. Iki haftalık süre boyunca Grup 1 'deki hastalara fizik tedavi, Grup 2'deki hastalara ise tedaviye ek olarak tramadol iyontoforezi uygulandı. Hastalar tedaviden önce, 10. seansı takiben ve 1. ve 3. aylarda görsel ağrı skalası (GAS) ve Western Ontario ve McMaster Üniversiteleri Osteoartrit İndeksi (WOMAC) kullanılarak ağrı ve fonksiyonel kapasitelerine göre değerlendirildi.

Bulgular: Yaș ortalaması ve ortalama ağrı süresi kontrol grubunda $58,53 \pm 8,38$ ve $5,00 \pm 2,66 \mathrm{yll}$, tramadol iyontoforez grubunda ise $58,15 \pm 7,70$ ve $4,71 \pm 2,70$ yıldı. Tedavi öncesinde gruplar arasında yas ortalamaları, ortalama ağrı süresi, vücut kitle indeksi, VAS ve WOMAC skorları açısından anlamlı fark yoktu. 10. seansı takiben ve 1. ve 3. aydan sonra, bașlangıç değerleriyle karșılaștıııldığında her iki grupta GAS ve WOMAC skorlarında anlamlı düșüș saptandı $(p<0.001)$. 10. seansı takiben, tramadol iyontoforez grubunda GAS skorları kontrol grubuyla karșılaștırıldığında anlamlı olarak düșük bulundu $(p<0.001)$. Ancak, tramadol iyontoforez ve kontrol gruplarının WOMAC skorları arasında anlamlı fark yoktu ( $p>0.05)$.

Sonuç: Fizik tedaviye eklenen tramadol iyontoforezin tedavi dönemi sırasında diz OA ağrısını rahatlatmada faydalı olabileceği sonucuna vardık.

(Turk J Rheumatol 2010; 25: 174-8)

Anahtar sözcükler: Diz osteoartriti, iyontoforez, tramadol, fizik tedavi

Alındığı Tarih: 29.11.2008 Kabul Tarihi: 16.05.2009

Presented in $16^{\text {th }}$ European Congress of Physical and Rehabilitation Medicine 3-6 June 2008 Brugge, Belgium

Address for Correspondence: Dr. Ayşe Dicle Turhanoğlu, Mustafa Kemal Üniversitesi Tıp Fakültesi, Fiziksel Tıp ve Rehabilitasyon Anabilim Dalı, Hatay, Turkey Phone: +903262455114 E-mail: adat@ttmail.com 


\section{Introduction}

Osteoarthritis (OA) is the most common form of arthritis. There is no cure for OA and today this disease is usually managed by a combination of several treatments. The goal of the treatment is to control pain, with accompanying increase in the ability to perform daily activities secondary to decreased pain (1). The therapeutic approach is mainly directed at symptoms, and many treatment options, including non-pharmacological and pharmacological measures, are recommended in the management of OA. Although non-steroidal antiinflammatory drugs (NSAIDs) are widely used in symptomatic treatment of OA, NSAID therapy involves potential hazards including gastrointestinal side effects (2). Physical agents are devices using physical modalities to produce beneficial therapeutic effects. Topical applications of heat or cold can be a helpful adjunct to the therapeutic plan for the OA patient. These are more effectively used in superficial joints, such as the knees, than in deep joints (2). In the last two decades, many advances have been made in the field of drug delivery, with resulting enhancements in the efficacy and safety of treatment and in the timeliness and convenience of treatment for the patient (3). Some of the more dramatic developments are technologies that allow the non-invasive transdermal delivery of several ionizable drugs, including lidocaine, fentanyl, morphine, and corticosteroids (3). This delivery is accomplished by iontophoresis, a process by which an electrical field is used to drive charged particles across the skin (3). lontophoresis uses electrical fields to force electrically charged or polarized atoms and molecules into tissue. Speed of movement is related to voltage and field strength, whereas the amount of material introduced into the tissue is proportional to the current. Penetration may be particularly intense at sweat glands and areas of skin breakdown, and depends on a substance's size and polarity (4). An iontophoretic unit is simple and may be contained within a disposable skin patch. In general, it consists of a direct current power source, two electrodes, and a pad moistened with a dilute solution of the desired (charged or polar) substance placed under the electrode of the same polarity. Currents are determined by multiplying the area of the active electrode by 0.1 to 0.5 $\mathrm{mA} / \mathrm{cm}^{2}$ (4). Tramadol has been used for the symptomatic relief of OA. Tramadol is a centrally acting, synthetic analgesic. Its mechanism of action involves weak binding to the $\mu$-opioid receptors and inhibition of reuptake of both norepinephrine and serotonin. It has been used to treat moderate-to-severe pain for 30 years in Europe and more than 10 years in the United States (5).

In this prospective study trial, our aim was to evaluate whether tramadol iontophoresis added to therapy is superior to the therapy methods alone, including transcutaneous electrical nerve stimulation (TENS), hot pack (HP), ultrasound (US), and exercise therapy in patients with knee OA.

\section{Materials and Methods}

According to a power analysis for visual analogue scale (VAS) scores in patients, we calculated that 20 patients in each group would be required to demonstrate a maximum difference $=1.6 \quad(S D=1.7)$ among groups $(\alpha=0.05, \beta=0.2)$.

The study population consisted of 84 women, with 42 in the control group and 42 in the iontophoresis group who admitted to the outpatient clinic of Physical Medicine and Rehabilitation. Based on the computer-generated random sequence, 84 patients were allocated randomly into two groups. However, 11 patients in the control group and 1 patient in the iontophoresis group were excluded from the study because of inadequate data records. A total of 72 patients who admitted to the outpatient clinic of Physical Medicine and Rehabilitation were included in this study. Approval by the local ethics committee and informed consent from the patients were obtained before the study. The diagnosis was based on the American College of Rheumatology (ACR) criteria for knee OA (6). All patients were initially questioned about age, weight, height, and duration of knee pain, and the patients were randomly separated into two groups. The physician initially examined all participants with regard to the selection criteria, which included clinical presentation of bilateral knee OA. Patients symptomatic for at least six months with the knee as the primary source of pain and disability and with Kellgren-Lawrence scores (7) grade II-III were included in the study. Patients were excluded from the study if they had any systemic illness or abnormal laboratory test results, were under any physiotherapy program or received intraarticular injections in the preceding year, or had symptoms or signs of acute synovitis. Following a 10-day washout period, the patients were invited to the physiotherapy session. Concomitant use of analgesics was not permitted throughout the study. Group 1, the control group, received physical therapy including TENS, HP, US, and exercises, while Group 2 received tramadol iontophoresis in addition to the TENS, HP, US and exercise therapy for a total of 10 sessions in a 2-week period. TENS (Chattanooga Intelect 2773 MS, USA), HP (Whitehall thermal pack, USA) and US (Medserve Prosound ULS-1000, USA) were applied to the superomedial and lateral parts of the knee by the same therapist. Before the application of iontophoresis (Chattanooga Intelect 2773MS, USA) $1 \mathrm{ml}$ of tramadol HCL (Contramal Abdi İbrahim Ltd., İstanbul, Turkey) was injected into a Chattanooga pad for each knee. Positive polarized electrode was chosen as the active electrode. The negative polarized electrode was located $25 \mathrm{~cm}$ from the active electrode. Tramadol iontophoresis was applied 
for 20 minutes (min) with enhancing galvanic flow amplitude up to a maximum $4 \mathrm{~mA}$.

Patients were evaluated regarding pain and functional capacity by using VAS and Western Ontario McMaster Universities Osteoarthritis Index (WOMAC) $(8,9)$ before therapy and following the 10th session, and 1 month and 3 months later. The WOMAC questionnaire consists of three items: pain, stiffness and physical function. The WOMAC scores were recorded on a Likert scale of 0 to 4 [ $0=$ no pain/limitation, $1=$ mild pain/limitation, $2=$ moderate pain/limitation, $3=$ severe pain/limitation, and $4=$ very severe pain/limitation]. Maximum scores for pain, stiffness and physical function were 20, 8 and 68 , respectively, with a total score of 96 .

\section{Statistical analysis}

SPSS 9.0 for Windows package program was used for statistical analysis. All continuous variables were tested for normal distribution by the Kolmogorov-Smirnov test. Bonferroni-adjusted Mann-Whitney $U$ test was used to compare ordinal variables between the two groups. Repeated measurements of WOMAC and VAS scores were compared using Friedman test, and $p$ values $<0.05$ were considered significant.

\section{Results}

The study population consisted of 72 women, with 31 in the control group (Group 1) and 41 in the iontophoresis group (Group 2). The mean age and duration of the knee pain were $58.53 \pm 8.38$ (95\% confidence interval $[\mathrm{Cl}$, $55.53-61.53)$ and $5.00 \pm 2.66(95 \% \mathrm{Cl}, 4.04-5.96)$ years in controls and $58.15 \pm 7.70(95 \% \mathrm{Cl}, 55.75-60.55)$ and $4.71 \pm 2.70(95 \% \mathrm{Cl}, 3.87-5.55)$ years in the tramadol iontophoresis group ( $p=0.843$ and 0.573 , respectively). There were no significant differences between groups regarding the mean age and duration of the knee pain, BMI, VAS and WOMAC scores. Following the 10th session, VAS and WOMAC scores were significantly decreased in both groups when compared with the values before the therapy $(p<0.001)$. After 1 and 3 months, WOMAC scores remained significantly lower in both groups $(p<0.001)$.

Visual Analogue Scale scores were significantly lower in the tramadol iontophoresis group compared to controls following the $10^{\text {th }}$ session $(p<0.001)$. Differences in VAS score changes between the two groups were not significant at 1 and 3 months. However, no significant difference was found in WOMAC scores between the tramadol iontophoresis and control groups ( $p>0.05)$ (Table 1). No significant side effects or complications were observed.

\section{Discussion}

In this study, marked improvements in clinical parameters were obtained in both the tramadol iontophoresis and control groups in patients with knee OA. It was observed that tramadol iontophoresis was only superior regarding VAS scores as determined a short time after the therapy.

The primary goals in OA therapy are to relieve pain, to secure and maintain the function and to minimize the deformity. Electrotherapy is widely used for the treatment of acute and chronic pain. Physiotherapy techniques are valuable therapeutic adjuvants for the treatment of OA symptoms (10). The mechanism of action of physical modalities on alleviation of joint pain is not yet clear. A group of agents called superficial and deep heaters are said to act by elevation of the temperature of tissue perfusion, increased metabolic activity and muscle relaxation. Another possible mechanism of action is the inhibition of nociceptive transmission by activation of A-alpha and A- beta fibers (11). Electrical currents such as TENS, with low frequency and high amplitude, are also thought to induce endogenous opioid secretion and modulate the ascending pain-control pathway (4). Physical treatment modalities are widely prescribed together with exercise; however, there is no agreement about which modality might be better than the other when combined with exercises (12). The optimum combination of treatment modalities has yet to be

Table 1. VAS and WOMAC scores of the patients with OA before and after treatment (Tx)

\begin{tabular}{lccccccccc}
\hline GROUP & & $\begin{array}{c}\text { VAS } \\
\text { Baseline }\end{array}$ & $\begin{array}{c}\text { VAS } \\
\text { After Tx }\end{array}$ & $\begin{array}{c}\text { VAS } \\
\text { 1 month }\end{array}$ & $\begin{array}{c}\text { VAS } \\
\text { 3 months }\end{array}$ & $\begin{array}{c}\text { WOMAC } \\
\text { Baseline }\end{array}$ & $\begin{array}{c}\text { WOMAC } \\
\text { After Tx }\end{array}$ & $\begin{array}{c}\text { WOMAC } \\
\text { 1 month }\end{array}$ & $\begin{array}{c}\text { WOMAC } \\
\text { 3 months }\end{array}$ \\
\hline Control & Minimum & 6 & 4 & 5 & 6 & 46 & 30 & 20 & 20 \\
& Maximum & 9 & 9 & 9 & 9 & 100 & 80 & 96 & 88 \\
& Median & $8^{*}$ & $6 \#$ & 6 & 7 & $73^{*}$ & 50 & 55 & 60 \\
\multirow{5}{*}{ lontophoresis } & N & 31 & 31 & 31 & 31 & 31 & 31 & 31 & 31 \\
& Minimum & 4 & 2 & 4 & 4 & 26 & 11 & 20 & 18 \\
& Maximum & 9 & 7 & 9 & 9 & 100 & 91 & 88 & 85 \\
& Median & $8^{*}$ & 4 & 7 & 8 & $71 *$ & 52 & 53 & 55 \\
& $\mathrm{~N}$ & 41 & 41 & 41 & 41 & 41 & 41 & 41 & 41 \\
\hline
\end{tabular}

* Significant difference between the baseline and after therapy, and at 1 and 3 months within groups, \# Significant difference between the groups when the distinction with the baseline scores was compared (with Bonferroni correction)

VAS: Visual analogue scale, WOMAC: Western Ontario McMaster Universities Osteoarthritis Index, OA: Osteoarthritis 
clarified (12). Osiri et al. (13) performed a recent metaanalysis of the literature concerning the use of TENS for knee pain in individuals with knee OA. They concluded that TENS was more effective than placebo when it was used for a duration of four weeks or more. In the present study, we observed a significant improvement regarding both WOMAC and VAS scores at 1 and 3 months following therapy when compared to pre-therapy values in patients receiving 10 sessions of therapy in 2 weeks. One important limitation of our study is that no placebo physical therapy was available. This practice was not technically probable in our study. Moreover, patients can easily distinguish sham therapy from the real one. Iontophoresis application was not superior to the other physical therapy with respect to WOMAC scores. However, one can argue that tramadol iontophoresis enhanced the effectiveness of the therapy according to VAS scores following the end of therapy. Tramadol shows its opioid agonist effect weakly at the $\mu$-receptors, and even weaker at the $\delta$ - and $\kappa$-receptors (14). In joints, endogenous opioid peptides have been identified in human inflamed synovium, where they are thought to act on intraarticular opioid receptors to reduce joint pain (15). Peripheral administration of morphine to knee joints reduces postoperative pain associated with arthroscopic surgery (15). Morphine exerts its analgesic effects by binding to $\mu$-opioid receptors present on primary afferent nerve terminals in the joint. Activated $\mu$-opioid receptors inhibit the local release of sensitizing neuromediators such as substance-P, and joint pain is alleviated (16). Tramadol inhibits presynaptic noradrenaline and serotonin reuptake in addition to its weak $\mu$-opioid receptor agonist effect (17). Thus, it is thought to potentialize the endogenous analgesia system via both its opioid agonist mechanism and monoaminergic effect. Recently, tramadol was shown to result in significant reduction in propofol injection pain (18), and was also suggested to have a local anesthetic effect when given intradermally (18). Intraarticular injection of tramadol was found superior to placebo in patients with $\mathrm{OA}$, and intraarticular $100 \mathrm{mg}$ tramadol provided excellent analgesia after arthroscopic surgery (19). Tramadol iontophoresis was found effective in relieving OA pain in our study as well. However, after the first month, the effectiveness of the therapy could not be seen. The activity is expected to be continuous in the management of chronic pain such as in OA. However, almost all of the available current OA therapies have temporary effects. Tramadol was reported to provide pain control when used as alternative or supplementary to NSAIDs in a study where it was compared to diclofenac (20). The American Geriatric Society reported that patients receiving chronic opioid therapy have fewer life-threatening risks than those who receive long-term NSAID therapy (21). Systemic tramadol has some side effects like nauseavomiting, constipation and respiratory depression, although with low frequency (22). We did not observe any systemic side effect in the present study. Application of drugs via transdermal route using iontophoresis is a non-invasive, effective and safe method (3). The lipophilic nature and brick and mortar structure of the skin normally pose problems for the transdermal delivery of therapeutic agents; however, the use of iontophoresis substantially increases penetration capacity, particularly of agents that are positively charged, lipophilic and small in size (23). Iontophoresis functions via two main mechanisms: (1) electrical repulsion of the ionized drug from the electrode and (2) electro-osmosis of the drug via solvent into the stratum corneum (24). Tramadol is a racemic mixture consisting of two enantiomers ([+] tramadol and [-] tramadol). Both enantiomers are pharmacologically active and involved in the inhibition of pain. (+) tramadol shows its effects as an opioid agonist whereas (-) tramadol inhibits noradrenaline reuptake. (+) tramadol is 10 times more active than (-) tramadol in analgesic efficiency $(24,25)$. Based on these characteristics, tramadol is one of the appropriate drugs for iontophoresis. To our knowledge, no previous studies have evaluated the effect of tramadol iontophoresis on knee OA. No significant side effects or complications were observed. A randomized study evaluated the safety and effectiveness of $2 \%$ lidocaine $\mathrm{HCL}$ iontophoresis in children. The authors concluded that iontophoresis is safe and effective (26). A controlled trial studied the benefits of $0.4 \%$ dexamethasone iontophoresis in conjunction with traditional physical therapy in the treatment of plantar fasciitis. Benefits over traditional therapy alone, although present, were transient and had disappeared at follow-up 1 month after the end of treatment. Iontophoretic therapy of herpetic neuralgia with methylprednisolone and lidocaine has been reported to have benefits that extend over a period of years (4).

In the present study, tramadol iontophoresis, although temporary, was found superior in comparison to traditional therapy. However, this superiority was limited to the therapy period, and no significant differences were found regarding the pain levels between the groups at 1 and 3 months after treatment. Furthermore, this superiority in relieving pain did not extend to WOMAC scores. This may be due to our relatively short-term therapy with only 10 sessions. Thus, it can be said that further studies with longer-term therapies are required.

\section{Conflict of Interest}

No conflict of interest declared by the authors.

\section{References}

1. Metcalf HM, Larson RV. Painful disorders of thigh and knee. In: Loeser JD (ed). Bonica's Management of Pain. Philadelphia: Lippincott, Williams \& Wilkins 2001: 1593-613.

2. Lozada CJ. Management of osteoarthritis. In: Harris ED, Budd RC, Firestein GS, Genovese MC, Sergent JS, Ruddy S, 
Sledge CB (eds). Kelley's Textbook of Rheumatology. Philadelphia: Elsevier Saunders 2005: 1528-40.

3. Witkowski TA, Viscusi ER. Iontophoresis: the process behind noninvasive drug delivery. Reg Anesth Pain Med 2005; 30: 292-4.

4. Basford JR. Therapeutic physical agent. In: Delisa JA (ed). Physical Medicine and Rehabilitiation Principle and Practice. Philadelphia: Lippincott, Williams \& Wilkins 2005: 252-70.

5. Mongin G. Tramadol extended-release formulations in the management of pain due to osteoarthritis: Expert Reviews of Neurotherapeutics. (Serial online): 2007: (12 screens): Available from: URL:http//www.expertreviews.com/doi/ abs/1.1586/14737175.7.12.1775. December 2007.

6. Altman R, Asch E, Bloch D, Bole G, Bornstein D, Brandt K, et al. Development of criteria for the classification and reporting of osteoarthritis. Classification of osteoarthritis of the knee. Diagnostic and Therapeutic Criteria Committee of the American Rheumatism Association. Arthritis Rheum 1986; 29: 1039-49.

7. Kellgren J, Lawrence J. Radiological assessment of osteoarthritis. Ann Rheum Dis 1957; 16: 494-501.

8. Bellamy N, Buchanan WW, Goldsmith $\mathrm{CH}$, Campbell J, Stitt LW. Validation study of WOMAC: a health status instrument for measuring clinically important patient relevant outcomes to antirheumatic drug therapy in patients with osteoarthritis of the hip or knee. J Rheumatol 1988; 15: 1833-940.

9. McConnell S, Kolopack P, Davis AM. The Western Ontario and McMaster Universities Osteoarthritis Index (WOMAC): a review of its utility and measurement properties. Arthritis Care Res 2001; 45: 453-61.

10. Henroitin $Y$, Crielaard JM. Scientific basis of physical therapy and rehabilitation in the management of patients with osteoarthritis. In: Reginster JY, Pelletier JP, Martel-Pelletier J, Henrotin Y (eds). Osteoarthritis Clinical and Experimental Aspects. Berlin: Springer 1999: 453-79.

11. Melzack R, Stillwell DM, Fox EJ. Trigger points and acupuncture points for pain correlations and implications. Pain 1977; 3: 3-23.

12. Cetin N, Aytar A, Atalay A, Akman MN. Comparing hot pack, short wave diathermy, ultrasound, and TENS on isokinetic strength, pain and functional status of women with osteoarthritic knees: a single blind, randomized, controlled trial. Am J Phys Med Rehabil 2008; 87: 443-51.

13. Osiri M, Welch V, Brosseau L, Shea B, McGowan J, Tugwell P, Wells G. Transcutaneous electrical nerve stimulation for knee osteoarthritis. Cochrane Database Syst Rev 2000; 4:CD002823.
14. Cepeda SM, Camargo F, Zea C, Valencia L. Tramadol for osteoarthritis: a systematic review and metaanalysis. J Rheumatol 2007; 34: 543-55.

15. Stein C, Hassan AH, Lehrberger K, Giefing J, Yassouridis A. Local analgesic effect of endogenous opioid peptides. Lancet 1993; 342: 321-4.

16. Yaksh TL. Substance $P$ release from knee joint afferent terminals modulation by opioids. Brain Res 1988; 458: 319-24.

17. Raffa RB, Friderichs E, Reimann W, Shank RP, Codd EE, Vaught JL. Opioid and nonopioid components independently contribute to the mechanism of action of tramadol, an "atypical" opioid analgesic. J Pharmacol Exp Ther 1992; 260: 275-85.

18. Pang WW, Mok MS, Chang DP, Huang MH. The peripheral analgesic effect of tramadol in reducing propofol injection pain: a comparison with lidocaine. Reg Anesth Pain Med 1999; 24: 246-9.

19. Alagöl A, Calpur OU, Kaya G, Pamukçu Z, Turan FN. The use of intraarticular tramadol for postoperative analgesia after arthroscopic knee surgery: a comparison of different intraarticular and intravenous doses. Knee Surg Sports Traumatol Arthrosc 2004; 12: 184-8.

20. Pavelka K, Peliskova Z, Stelilikova H, Ratcliffe S. intra individual differences in pain relief and functional improvement in osteoarthritis with diclofenac or tramadol. Clin Drug Invest 1998; 16: 421-9.

21. American Geriatric Society panel on chronic pain in older persons. The management of chronic pain in older persons. J Am Geriatric Soc 1998; 46: 635-51.

22. Miyoshi RH, Leckband SG. Systemic opioid analgesic. In: Loeser JD (ed). Bonica's Management of Pain. Philadelphia: Lippincott, Williams \& Wilkins 2001: 1682-709.

23. Barry BW. Novel mechanism and devices to enable successful transdermal drug delivery. Eur J Pharm Sci 2000; 14: 101-14.

24. Raffa RB, Friderichs E, Reimann W. Complementary and synergistic antinociceptive interaction between the enantinomers of tramadol. J Pharmacol Exp Ther 1993; 267: 331-40.

25. Goeringer KE, Logan BK, Christian GD. Identification of tramadol and its metabolites in blood from drug-related deaths and drug impaired drivers. J Anal Toxicol 1997; 21: 529-37.

26. Galinkin JL, Rose JB, Harris K, Watcha MF. Lidocaine iontophoresis versus eutectic mixture of local anesthetics (EMLA) for iv placement in children. Anesth Analg 2002; 94: 1484-8. 